\title{
An Economic Analysis of Capital Flight from Nigeria
}

\author{
Taiwo Olubanjo Ajilore \\ Department of Economics, Faculty of Social Sciences \\ Obafemi Awolowo University, Ile-Ife, Nigeria \\ Tel: 234-803-4018007 E-mail: otajilore@oauife.edu.ng or speak_2_ajilore@yahoo.com
}

\begin{abstract}
Available estimates of capital flight from Nigeria have several important limitations. This study takes cognizance of these limitations in estimating and subsequent analysis of trends of capital flight flows in Nigeria for the periods $1970-2004$ using the residual method of estimation, including necessary adjustments to account for the influence of trade faking and exchange rates movements. The study further seeks to verify if capital flight is indeed an important concern to economic management in Nigeria by exploring various economic issues that existing body of theoretical and empirical literature had linked to capital flight. For most of the periods, capital flight estimates had positive sign, indicating that residents consistently took capital out of Nigeria. The study further documented that trade faking is an important means through which capital flight is effected in Nigeria, with evidences that confirmed the existence of financial revolving door relationship between capital flight and external indebtedness in Nigeria. The study emphasized the need for decisive policies to strengthen macroeconomic management and macro-organizational fundamentals. A rather flexible trade and exchange regimes that result in a lowering down of tariff duties, and a more market determined exchange rates, are likely to wipe out the incentives for fabrication of traded values of exports and imports.
\end{abstract}

Keywords: Capital Movements, Trade Faking, Estimates, Trends, Nigeria

\section{Introduction:}

The Nigerian economy in the period preceding structural adjustment was characterized by macroeconomic instability, being a natural consequence of manifold factors that include, but not restricted to political tensions and instability, wrong or lacking incentive structures and institutions to make markets efficiently coordinate demand and supply, as well as heavy government involvement which put markets at the sideline. Whatever the exact reasons, when a country experiences macroeconomic instability, it manifests in a number of ways: budget deficits will rise, current account deficits increase, exchange rate overvaluation occurs and inflation grows. These were peculiar characteristics of the Nigerian macro economy during these periods. Incidentally, variables describing such phenomenon are often found in studies on the determinants of capital flight.

Capital flight refers to any illicit movement of capital away from a domestic to a foreign economy. It is normally done in such manners that circumvent the regulatory purview of the domestic authorities. In the contemporary literature of development economics, there has been increasing attention to the notion of capital flight. Many analysts have attributed sluggish economic growth and persistent balance of payments deficits in most developing counties to capital flight (Ajayi, 1996). Capital flight is a particularly serious and important concern for a developing country like Nigeria. First, capital is scarce in the developing world, so capital flight contributes to worsening the capital scarcity problem. In addition, it also restricts the capacity and ability of affected countries to mobilize domestic resources and access foreign capital necessary to finance economic growth and development. Consequently, capital flight can contribute to the retardation of economic growth and development of developing countries. Second, capital flight can lead to a negative feedback. Because of the resulting tightening of capital constraints and the possibility of being cutoff from foreign capital, even more capital flight could occur and consequently, progressive economic policies become more difficult to implement and raising social conditions a heavier burden to solve.

These issues are significant for Nigeria, as substantial empirical researches have expressed concerns about the magnitude, causes and consequences of these capital outflows. (See amongst others; Ajilore (2005), Onwioduokit (2001); Ajayi (1992, 1996, 1997); Boyce and Ndikumana, 2001; Murinde et al., 1996; Nyatepe-Coo, 1994; Hermes and Lensink, 1992; Ojo, 1992; Chang and Cumby, 1991; Morgan Guaranty, 1986, Lensink, Herms and Murinde (1998)). Adedeji (2001), using the World Bank (1985) definition of capital flight, presents statistics on evolution of capital flight from Nigeria during the periods 1972 - 1999. It showed an annual average of US \$496 million during $1972-1979$, increased to US $\$ 1,478$ million in the pre-crisis period (1980-86) and further increased to annual average of US $\$ 3,071$ million during $1987-94$. This trend points to the fact that higher capital flight precedes 
external crisis, while the resulting macroeconomic instability might have produced the increase in capital flight thereafter.

Capital flight, largely because of its loose definition, is very difficult to measure. Notwithstanding these limitations, a reasonably accurate estimates of scale and persistent of capital flight is important for a proper diagnosis of and prescription for many macroeconomic ills. In spite of its importance, measurement of flight capital has remained a matter of dispute. Eggerstedt, Hall and Wijnbergen (1993), making use of Mexico as case study, demonstrated the effects of using various approaches reported in literature against another. Applying a common data set and time period, they discovered almost a $100 \%$ difference between the highest and the lowest estimate of capital flight over the period. These authors survey the most important data and conceptual disputes underlying the differences, and provided theoretical arguments on how to make computational adjustments in order to harmonize these discrepancies.

Available estimates of capital flight from Nigeria have several important limitations. First, they cover only a fairly short period of time, which limits our ability to examine the trends in capital flight, especially over the period of time subsequent to financial reform implementation in Nigeria. To our knowledge, existing estimates of capital flight in Nigeria include that of Ajayi (1992) for period 1972 - 1989, Ojo (1992) for period 1975 - 1991, Nyatepe-Coo (1994) for period 1970 -1992, Adedeji (2001) for period 1972 - 1999, Ajilore (2005) for periods 1970 - 2001 and Lawanson (2006) for 1970 -2001. Second, while these studies made use of variants of the residual methods of estimating capital flight, they failed to take cognizance of a number of computational adjustments necessary to harmonize variances in alternative estimates of capital flight, as have been proposed in empirical literature. (See e.g. Eggerstedt, Hall and Wijnbergen (1993), Chang et al. 1997; Claessens 1997; Boyce and Ndikumana 2001). One of such adjustment in the capital account is for the impact of foreign exchange fluctuations on total external debt. Long-term external debts are denominated in hard currencies (e.g. British Pound, Japanese yen, German mark, United States dollar, etc.) and currency fluctuations affect their respective values across periods. Depending on whether these currencies depreciate or appreciate against the dollar, it introduced a downward or upward bias in measured capital flight. With the exception of Ajayi (1992), past estimates pay no attention to the effects of falsification of trade transactions in estimating capital flight. Export under invoicing and import over invoicing both inflate the current account deficit recorded in the balance of payments, while import under invoicing leads to its understatement. If the current account deficit is understated, the residual estimate of capital flight will be too high, while reverse is true when it is overstated.

The present study takes cognizance of these shortcomings in estimating and subsequent analysis of trends of capital flight flows in Nigeria. The study further seeks to verify if capital flight is indeed an important concern to economic management in Nigeria by exploring various economic issues that existing body of theoretical and empirical literature had linked to capital flight. The rest of the paper proceed as follows: following this introductory section, section 2 presents the methodological frameworks and data sources for estimating capital flight from Nigeria over the period of analysis, section 3 presents the estimates and analyses of the trends and magnitudes of capital flight flows from Nigeria, section 4 illustrates why capital flight is an important concern for Nigeria by exploring a number of issues linked to capital flight in empirical literature, while section 5 concludes with policy recommendations.

\section{Methodology for Estimation of Capital Flight Flows}

In this study, we interpreted capital flight as consisting of private capital outflows of any kind that result in the acquisition of foreign assets by the residents of a country. As such, the residual method estimate of capital flight best captures this interpretation. Estimation of capital flight, therefore, involves an analysis of the official (World Bank and IMF) statistics for the derivation of a "residual" measure of capital flight. Following Boyce and Ndikumana (2001; 2002), and Ndikumana and Boyce (1997) and according to the residual approach developed by the World Bank, we define capital flight as the difference between capital inflows and foreign exchange outflows. The rationale behind such characterization lies in the argument that any inflow that does not finance the current account deficit or adds to reserves flees the country in the form of capital flight. Accordingly, flows that do not go to either account are regarded as capital flight. More specifically, a surplus of inflows over reported uses reflects positive capital flight.

Our methodology, including necessary adjustments, is as follows:

$$
\mathrm{KF}_{\mathrm{t}}=\Delta \mathrm{DEBT}_{\mathrm{t}}+\mathrm{FDI}_{\mathrm{t}}-\left(\mathrm{CA}_{\mathrm{t}}+\Delta \mathrm{RESs}_{\mathrm{t}}\right)
$$

Where KF refers to capital flight, $\Delta$ Debt refers to change in total external debt stock, FDI refers to the net flows of foreign investment, CA refers to the current account balance, and $\triangle \mathrm{RES}$ refers to the changes in the accumulation of 
foreign exchange reserves. Equation (1) obtains the baseline capital flight. Positive estimates mean capital flight; negative mean "reverse" capital flight, (i.e. net unrecorded capital inflows). Note that the right hand side of equation (1) shows the official or recorded transactions reported in the BOP and so, KF implies the "unrecorded" capital outflows.

However, Boyce and Ndikumana (2001) stressed that computational adjustments need to be made in order to account for some errors in the data, in particular errors in the capital account and in the current account. Relying on the methodology of these authors, the basic residual measure presented above is then refined by applying necessary adjustment as follows. First of these adjustments concerns the country's external debts, specifically the long-term external debts, which are normally from different countries and expressed in their respective denominations. This procedure suggests that currency fluctuations will affect the respective values of external debts of a country across periods. To obtain the external debt adjustments for currency fluctuations, using the approach of Boyce and Ndikumana (2001), we re-estimate DEBT in the following way,

$$
\begin{aligned}
N E W D E B T_{t-1} & =\sum_{n=1}^{7}\left[\left\{\alpha_{n, t-1} * L T D E B T_{t-1}\right\} /\left\{F X_{n, t} / F X_{n, t-1}\right\}\right]+I M F_{t-1} /\left\{S D R_{t} / S D R_{t-1}\right\}+U S D E B T_{t-1}+ \\
& M U L T I P L E_{t-1}+O T H E R_{t-1}+S T D E B T_{t-1}
\end{aligned}
$$

where NEWDEBT is adjusted total external debt; LTDEBT is the total long-term debt; $\alpha_{n}$ is the proportion of long-term debt held in currency $\mathrm{n}$, for each of the seven non-US currencies. The seven non-US currencies are UK pounds, French franc, Deutsche mark, Japanese yen, Swiss Franc, SDR, and recently from 2001, the Euro. FX is the end-of-year exchange rate of the currency denominated against the dollar expressed as units of currency per US dollar, and so $\mathrm{FX}_{\mathrm{n}, \mathrm{t}} / \mathrm{FX}_{\mathrm{n}, \mathrm{t}-1}$ is a ratio representing the exchange rate fluctuation between two periods; IMF is the use of IMF credit; SDR is special drawing rights, and so $\mathrm{SDR}_{t} / \mathrm{SDR}_{\mathrm{t}-1}$ is a ratio representing the SDR fluctuation between two periods, USDEBT is external debt in US dollars; MULTIPLE is external debt in multiple currencies (other than those mentioned above and not in OTHER); OTHER for unspecified currencies; and STDEBT is short-term external debt. Equation (2) has to be modified for the Nigerian case because Nigeria does not use IMF credit facility. Use of IMF credit is thus exempted from equation (1) to have:

$$
\begin{gathered}
N E W D E B T_{t-1}=\sum_{i=1}^{7}\left(\frac{\alpha_{i, t-1} * L_{T} / F E B T_{t-1}}{F X_{i, t} / F X_{i, t-1}}\right)+\text { USDEBT }_{t-1}+\text { MULTIPLE }_{t-1}+\text { OTHER }_{t-1} \\
+ \text { STDEBT }_{t-1}
\end{gathered}
$$

By definition

$$
\triangle \mathrm{DEBT}_{\mathrm{t}}=\mathrm{DEBT}_{\mathrm{t}}-\mathrm{DEBT}_{\mathrm{t}-1} \text {, }
$$

Following Boyce and Ndikumana (2001), we derive the series for adjusted external debt figure based on the following equations:

$$
\triangle \text { DEBTADJ }_{\mathrm{t}}=\mathrm{DEBT}_{\mathrm{t}}-\mathrm{NEWDEBT}_{\mathrm{t}-1}
$$

where $\triangle \mathrm{DEBTADJ}$ is the change in exchange rate adjusted external debt, and so to re-estimate capital flight, Equation 1 is modified into:

$$
\mathrm{KF}_{\mathrm{t}}=\Delta \mathrm{DEBTADJ}_{\mathrm{t}}+\mathrm{FDI}_{\mathrm{t}}-\left(\mathrm{CA}_{\mathrm{t}}+\Delta \mathrm{RES}_{\mathrm{t}}\right)
$$

The second adjustment concerns the current account data. Specifically, export and import data could be inaccurate because of systematic mis-invoicing of values of exports and imports (see e.g., Bhagwatti (1964) and Gulati (1987) for details). In countries with strong proclivities to capital flight, it is not unreasonable to assume that trade mis-invoicing may be utilized as a mechanism for flight. Residents can acquire foreign assets by over invoicing imports and under invoicing exports. However, domestic policies may encourage mis-invoicing in the reverse: imports may be under invoiced for the purposes of tariff evasion and export promotion schemes may generate an incentive for export over invoicing.

Such reverse misinvoicing results in an understatement of the current account deficit and consequently leads to an overstatement of the residually derived capital flight estimates. Owing to the presence of these counteracting effects, the net effects of trade misinvoicing upon capital flight estimates can go in either direction. Hence, a "net misinvoicing adjustment" applied to the basic residual will provide more accurate estimates of capital flight. We compute the export and import discrepancies for Nigeria through comparison of Nigeria's export and import data to those of its industrialized trading partners' exports and imports respectively. Since movement of funds from developing countries to developed countries is commonly tagged capital flight, investigation of trade mis-invoicing will be limited to trade discrepancies between Nigeria and her developed countries trade partners. 
Three steps are required to compute trade misinvoicing. The first is to compute export and import discrepancies for Nigeria in its trade with industrialized country partners.

$$
\begin{aligned}
& D X_{t}=P X_{t}-C I F \cdot X_{t} \\
& D M_{t}=M_{t}-C I F \cdot P M_{t}
\end{aligned}
$$

Where $D X_{t}$ and $D M_{t}$ are the total export and import discrepancies, respectively; $P X t$ is the value of the industrialized country trading partners' imports from Nigeria as reported by industrialized country trade partners, and $P M_{t}$ is the value of the industrialized country trading partners' exports to Nigeria as reported by industrialized country trade partners; $X_{t}$ and $M_{t}$ are Nigeria's exports to and imports from major trading partners, respectively, as reported by the country. $C I F$ is the c.i.f./f.o.b. factor to adjusting export data for cost of freight and insurance.

The second step is to calculate the global export and import discrepancies for trade misinvoicing by multiplying these discrepancies with the inverse of the shares of the major trading partners in Nigeria's exports and imports. The last step is to find the sum of export and import discrepancies from the second step to get total trade misinvoicing; that is,

$$
M I S_{t}=D X_{t}+D M_{t}
$$

We then add this calculation to Equation (1) to obtain total adjusted baseline capital flight (Adj KFt),

$$
\text { Adj KFt }=K F t+M I S t
$$

Finally, in order to make estimates of capital flight comparable across periods, we adjust for inflation by deflating equation (10) using the United States producer price index (PPI) with a base year of 2000, real capital flight is obtained:

$$
\text { Real } \mathrm{KFt}_{\mathrm{t}}=\text { AdjKFlight }_{\mathrm{t}} / \mathrm{PPI}_{\mathrm{t}}
$$

\section{Trends and Magnitudes of Capital Flight Phenomenon in Nigeria}

In this section, we describe the data on Nigeria's external debt, net foreign investment, current account and international reserve accumulation. These are data used in obtaining the baseline estimates of capital flight flows. The data we use were compiled from the IMF's Direction of Trade Statistics CDROM (2005), International Financial Statistics CDROM (2005) and the World Bank's Global Development Finance CD-ROM (online) and World Development Indicators CD-ROM (2005).

Table 1 presents the data used in the computation of baseline estimates of capital flight flows from Nigeria as given in equation (1). The table also contains the resultant baseline estimates of capital flight flows. Column 1 shows changes in the level of the countries total external debt stock. The trend of the data series clearly indicated Nigeria as a debt distressed economy, as the country recorded positive net increases in external indebtedness from a modest $\$ 61.25$ million in 1970 to a staggering $\$ 2,676.80$ million in 1980 and $\$ 3,316.90$ in 1990 . The 1990 s witnessed slight reductions in the level of external indebtedness, with a peak of \$4487.1million increases in 2003.

Column 2 shows the net flows of foreign direct investment. Net foreign direct investment flow was \$205 million in 1970 and grew to $\$ 309.6$ in 1979 , but with a reverse flow of $\$ 738.9$ in 1980 . The 1980 s witnessed consistent increases in net FDI flows peaking at $\$ 1884$.3million in 1989, followed by sudden drops through the periods 1990 to 1992. FDI flows averaged \$1350million in the period 1993 to 2004 peaking at \$2006 million in 2003.

Nigeria recorded current account (CA) surplus for most of the periods under considerations as indicated in column 3 of the table. The deficit years are 1974 to 1978 with average deficit of $\$ 1399.5$ million, 1982 - 1984 averaging \$6029 million and $1993-1995$ averaging \$1828.9 million deficit. The year $1970-1974$ witnessed consistent accumulation in foreign reserves peaking at $\$ 9,043$ million in 1974 , followed by a steady depletion between 1975 and 1978 , with an average yearly erosion of $\$ 928.96$ million. The trend generally indicates cyclical movements of accumulation and erosion of foreign reserves over the period of analysis.

Column 5 of the table shows the baseline estimates of capital flight flows from Nigeria based on Equation (1).

Making use of procedure outlined in equations (7) to (9) and data from IMF's Directions of Trade Statistics CD ROM 2005, supplemented with DOT Yearbook, various issues for early years, the data and the results of the calculation for the period $1970-2004$ are as presented in Table 2. Column 7, 8 and 9 of Table 2 presents respectively estimates of Export discrepancies, Import discrepancies and overall trade discrepancies over the period of analysis of this study.

As indicated in Figure 1, we take note that trade misinvoicing represents a substantial source of capital flight to Nigeria, with an average annual outflow of capital attributable to this mechanism running to the tune of \$386millon and cumulative total of $\$ 13.5$ billion over the 1970 - 2004 period. Estimates in Table 3 shows that the period 
preceding financial liberalization witnessed heavy hemorrhage of capital via trade misinvoicing, with an average annual outflow of $\$ 789.5$ million. This drastically reduced to an annual outflow of \$5million during the post liberalization years. This provide preliminary evidence that financial reforms might have likely relax the phenomenon of overvalued currencies and restricted access to foreign currencies which are often the setting and incentives for invoice alterations.

We also take note, as indicated in Figure 2 that export under invoicing remains the dominant source of trade faking in Nigeria over the period of analysis. Exports were under invoiced to the tune of $\$ 23.4$ billion (greater than cumulative trade misinvoicing) for the period $1970-2004$. On the average, it seems financial reforms has in no way affected the incentives for export under invoicing over the period of analysis. The explanation for this might be found in the fact that the programme of reforms in the financial system fails to put in place a system of incentives (such as special tariff regimes) to assist local exporters, thus they consistently resort to understate their export value to evade export tariffs. It is also of note that notwithstanding the implementation of reforms measures in the financial system, there consistently exist premium in the foreign exchange market in Nigeria. Consequently, foreign currencies can be bought and sold at a premium in the black market for foreign exchange.

Thus, export under-invoicing continues to provide an illicit source of foreign exchange earnings for speculative trading at the black market. It is expected that the foregoing scenario will motivate import over invoicing, however estimates in Table 4.2 above indicates the contrary. The estimates show that imports were heavily under invoiced especially during the period $1986-1991$. This might be an indication of policy inconsistencies associated with the implementation of the reforms programme in Nigeria. Imposition of high and prohibitive import duties (mainly to serve as source of government finance), and regimes of trade controls still accompanied the liberalization of trade policies of the period. In aggregates, import discrepancy serves as means of capital inflows (or flight reversal) over the period of analysis and for the post liberalization period.

Table 3 below presents estimates of capital flight flows from Nigeria based on the methodological procedures hitherto outlined. Column 1 presents the baseline estimates of capital flight based on the World Bank version of the residual method. Column 2 contains capital flight estimates that take into consideration exchange rate fluctuations in long-term debt, while column 3 contains capital flight estimates adjusted for trade mis-invoicing (Note 1). To make capital flight estimates comparable across periods, we calculate real capital flight using the United States producer price index (PPI) in constant 1995 prices as price deflator; this is contained in column 4.

As indicated in Figure 3, for most of the period, capital flight estimate has positive sign, which indicates that residents consistently took capital out of Nigeria. Estimates indicated capital flight reversal for the period 1970 $-1971,1980$ to 1981, 1985, 1987, 1990, 1996 to 1997, 2000 to 2001 and 2003 to 2004 . The peak of flight reversal of about \$10.6billion occurs in year 2000. For the rest of the period, there were capital flights from the country. Capital flight problem began with a modest outflow of $\$ 670.5$ million in 1972 , which consistently increased to peak at an all time highest level of $\$ 18.1$ billion in 1982. These trends indicate that the capital flight problem evolved with and is a consequence of structural distortions that characterized the repressed Nigerian economy. Basically, no distinct pattern is reflected in term of specific observable trend of the capital flight estimate, rather the estimates are characterized by fluctuations, which is similar to what obtains in other studies in the literature (e.g. Ajayi, 1992, 1997).

On the aggregate Nigeria lost a huge sum of $\$ 63.7$ billion dollars to illicit capital transfers over the period 1970 -2004. On the average, more than US\$18.8billion worth of capital was exported out of Nigeria annually over the period of analysis. Huge capital flights appear to concentrate in most of the years preceding financial liberalization. The annual average capital flight estimates of US\$3.6billion for the pre- reform period 1970-1986 significantly fell to US\$171million in the decades succeeding financial reforms. This succinctly supports the conjecture that favorable policy changes like opening the capital account and financial market integration discourage capital from fleeing. In summary, our estimates sufficiently indicate that capital flight phenomenon exists as an economic problem in Nigeria as have been sufficiently documented in earlier literature.

\section{Capital Flight from Nigeria: Some Economic Analysis}

In what follows, we illustrate why capital flight is an important concern for Nigeria; to this end, we explore a number of issues linked to capital flight in empirical literature.

The first issue is the relative burden of capital flight on the Nigerian economy. We investigate this by expressing its magnitude as a ratio of gross national product. The result is plotted in Figure 4. 
Capital flight as a percentage of GDP was rather high during the period 1970-2004, confirming that the episode is a genuine cause of concern to economic management in Nigeria. The annual average capital flight as a percentage during this period was 6.4 percent of GDP.

As indicated in figure 4, capital flight episode in Nigeria appears to have followed some political and economic trend. Tracing the relative burden of capital flight from 1970, the incidence was relatively insignificant between the years $1970-1978$, which represents the years of oil boom and military rule, capital flight during these period barely averaged 4 percent of GDP. The capital flight problem came to the fore between the period 1979 to 1984, which coincides with the oil glut and the affluent political regime of the first republic, capital flight constitute an all high $40 \%$ of GDP in 1983 and an average of 30\% during the period under review. The persistence and apparent volatility of the episode, despite arrays of economic reforms and restructuring programmes of successive regimes in the country suggest that the structural weakness in the economy may be an important reason explaining why private agents choose to take their wealth out of Nigeria rather than to invest it within the country. Splitting the trend into pre and post reforms periods, there seem to suggest that economic reforms that started in 1986 ameliorate the burden of capital flight as the post reforms period witnessed substantial episode of flight reversals. Also on the average, capital flight as a percentage of GDP is respectively 9.8 percent and 2.8 percent during these periods.

The second issue we explore is the conjecture whether economic performance dampens capital flight in the Nigerian situation. Conventional analysis suggests that economic growth implies high returns to capital, both domestic and foreign, and an attractive investment environment in general. As such, we expect capital not to flee in a high growth environment. This is expected because economic growth raises incentives for capital to remain in the domestic economy, and consequently discourages flight. To examine this link, we obtain growth rates of real gross domestic product (RGDP) and the share of real capital flight RGDP. The former allows a comparison of economic growth rates over time, while the latter shows the relative burden of capital flight to the economy over time. Figure 5 shows the trends. Figure 4.5 consistently showed a trend of increasing growth rates being accompanied by a declining capital flight, while reverse is also consistently true. We thus confirm a negative relationship between capital flight and economic performance in Nigeria. A corollary of the foregoing is also that economic crises or shocks induce capital flight. Two periods, 1982-1985 and 1992 to 1994 are of interest in figure 4.6. In both periods, there was an economic slowdown and a severe recession. The first period is associated with the oil price shocks and debt crises while the second is associated with the banking sector crises in Nigeria. These two periods recorded increases in the level of capital flight flows.

Thirdly, we examine the link between capital flight and external debt burden in Nigeria. This issue is significant for Nigeria, as it ranks very high in World Banks' classification of ten most heavily indebted countries with a total external debt obligation of over US\$34billion. Ajayi, (1995), asserts that as the severity of external indebtedness in most of these countries increases, so has capital flight problems exacerbated in these countries. This phenomenon describes a paradoxical revolving door of a bi-directional flow of capital, i.e. where capital enters the country in the guise of external borrowing and simultaneously slips out of the country as private capital flight. This contradicts the usual textbook understanding of the issue, which postulates that a favorable investment climate in any country would not only attract foreign capital, but also retain domestic investment.

Figure 6 graphs changes in debt and capital flight. Debt levels closely followed the trend in capital flight suggesting that at the very least, they are codetermined for most of the period of analysis. This result provides evidences that confirmed the existence of a financial revolving door relationship between the two variables

We explored the relationship between financial liberalization and capital flight. Conventional analysis suggests that favorable policy changes (like opening the capital account and financial market integration) will discourage capital from fleeing. The alternative view is that financial liberalization produces an environment that is relatively volatile for capital flows, creating uncertainty, and making the economy vulnerable to economic crises and thus capital flight. We examine this issue by analyzing the trends and patterns of movements in real capital flight measure before and after the implementation of financial liberalization measures in Nigeria.

Figure 7 illustrate that movements in real capital flight are different before and after 1986. Capital flight in the post-1986 period was relatively low. In fact, the levels were below the three-decade period average. In Figure 4.7, we see that after 1986, capital flight was less significant in size, but had large fluctuations, with figures way below the average of the preceding two-decade period average. Indeed, the period following financial reforms witnessed high frequency of capital flight reversal compared to the pre reforms period. We argue that the structural change in the movement of capital flight might be due to institutional changes in the country's financial system. Financial liberalization in the early 1990s allowed for large flows of capital. Accordingly, this had significant implications for the movement and size of capital flight. 


\section{Summary and Concluding Remarks}

This study estimates the magnitude and analyzes the trends of capital flight for the periods 1970 -2004 using the residual method of estimation, including necessary adjustments to account for the influence of trade faking and exchange rates movements. The study further illustrates why capital flight is an important concern for Nigeria by exploring a number of issues linked to capital flight in empirical literature.

For most of the periods, capital flight estimates has positive sign, indicating that residents consistently took capital out of Nigeria. On aggregate, Nigeria lost $\$ 63.7$ billion US dollars to illicit capital transfers over the period $1970-$ 2004. We also adjusted for trade faking in our capital flight estimates to derive another series of capital flight estimates. We discover that trade faking is an important means through which capital flight is effected in Nigeria. Over the period under study (1970-2004), a significant amount of under-invoicing of exports and over-invoicing of imports took place. An average annual outflow of capital attributable to this mechanism runs to the tune of \$386million and cumulative total of \$13.5 billion over the 1970 - 2004 period.

Some findings of policy relevance from this include:

i) Capital flight constitutes a genuine cause of concern to economic management in Nigeria, with an annual average capital flight as a percentage of GDP of 6.4 percent for the period $1970-2004$.

ii) Improvements in economic performance dampen capital flight, while economic crises or shocks accelerate it.

iii) Evidences confirmed the existence of a financial revolving door relationship between capital flight and external indebtedness in Nigeria.

iv) The period following financial liberalization witnessed high frequency of capital flight reversal compared to the pre-reforms period. This structural change might be due to institutional changes in the country's financial system.

This study had confirmed that not only is the country loosing substantial amounts of funds that could be otherwise used for development and further stabilization, capital flight also punishes long term economic growth. This implies that policy measures should be instituted to make the domestic economy more attractive for private investment if capital flight is to be confronted and flight capital recaptured. Perhaps it is time to revisit the importance of having decisive policies to strengthen macroeconomic management and macro-organizational fundamentals.

In addition, the study established that trade faking is an important means through which capital flight is effected in Nigeria. This is a pointer to the fact that there still exists a tight trade and foreign exchange regime that generates various financial incentives for traders to mis-invoice their traded values. They use the undisclosed resources to initiate parallel foreign exchange market activities and gain high black market premium. For policy, we suggest a rather flexible trade and exchange regime that results in a lowering down of tariff duties and a more market determined exchange rates. These are likely to wipe out the incentives for fabrication of traded values of exports and imports.

This study represents an important supplement to capital flight empirics in Nigeria by utilizing hitherto neglected refinements in methodological approaches to the estimation of magnitudes of capital flight from Nigeria. Unlike existing studies, it further identifies the major conduits for illicit capital movements from Nigeria.

\section{References}

Adedeji. (2001), “The Size and Sustainability of Nigerian Current Account Deficits" International Monetary Fund Working Paper 01/87 (Washington DC).

Ajayi, S. Ibi. (1992). “An Econometric Analysis of Capital Flight from Nigeria”, World Bank Working Paper Series, No.993 (Washington DC, World Bank)

Ajayi, S. Ibi (1996). "Capital Flight and External Debt in Nigeria”, African Economic Research Consortium Research Paper No.35.

Ajayi, S. Ibi. (1997). "An Analysis of External Debt and Capital Flight in the Severely indebted Low Income Countries in Sub-Saharan Africa", Research Department, International Monetary Fund Working Paper 68 (Washington DC).

Ajilore, O.T. (2005). "External Debt and Capital Flight in Nigeria: Is There a Revolving Door?. South African Journal of Economic and Management Sciences. Vol. 8 No.2. pp 47-56

Boyce J.K and L. Ndikumana. (2001). "Is Africa a Net Creditor? New Estimates of Capital Flight from Severely Indebted Sub-Saharan African Countries: 1970-1996”, Journal of Developing Studies, Vol.38, No.2. pp 112 -147 
Boyce, J.K. (1992). "The Revolving Door? External Debt and Capital Flight: A Philippine Case Study", World Development, Vol.20, No.3. pp 1342 - 1357

Boyce, J.K. (1993). The Philippines: The Political Economy of Growth and Impoverishment in the Marcos Era. London: Macmillan Press.

Chang, K., S. Claessens and R. Cumby. (1997). "Conceptual and Methodological Issues in the Measurement of Capital Flight" International Journal of Financial Economics Vol.2. No3 pp 45 -52

Claessens, S and D. Naudé. (1993). "Recent Estimates of Capital Flight”, Policy Research Working Paper Series No. 1186 (Washington DC, World Bank).

Claessens, Stijn. (1997). "Estimates of Capital Flight and Its Behavior." Revista de Análisis Económico, 12: pp 3-34.

Eggerstedt, H., R. Brideau Hall and S. van Wijnbergen (1995). "Measuring Capital Flight: A Case Study of Mexico". World Development, Vol.23, N0. 2.

Gulati, S.K. (1987). "A Note on Trade Misinvoicing", in Capital Flight and Third World Debt, edited by D.R. Lessard and J.Williamson (Washington DC: Institute for International Economics)..

Gupta, K.L and R. Lensink. (1996). Financial Liberalisation and Investment. Routledge, London.

Hermes, N and R. Lensink. (1992). "The Magnitudes and Determinants of Capital Flight: The Case of Six Sub-Saharan African Countries", The Economics, Vol. 140, No. 4. pp $76-81$

Hermes, N and R. Lensink. (2001). "Capital Flight and the Uncertainties of Government Policies", Economics Letters, Vol.71 No.3. pp 87 - 96

Lawanson A. Olayinka. (2006). Econometric analysis of capital flight from nigeria: a portfolio choice approach. Final Report Submitted to African Economic Research Consortium, Nairobi, KENYA

Lensink, R., N. Hermes, and Victor Murinde. (1998). "The Effect of Financial Liberalisation on Capital Flight in African Economies”, World Development, Vol.26 No.7. pp 1467- 1477

Lensink, Robert, Niels Hermes, and Victor Murinde. (2000). "Capital Flight and Political Risk." Journal of International Money and Finance, 19: 73-92.

Morgan Guaranty Trust Company. (1986). "LDC Capital Flight”, World Financial Markets Vol 2(March).

Murinde, V., N. Hermes and R. Lensink. (1996). "Comparative Aspects of the Magnitude and Determinants of Capital Flight in Six Sub-Saharan African Countries", Saving and Development, Vol. 20, No.1.

Ndikumana, L and K. Boyce. (1998). "Congo's Odious Debt: External Borrowing and Capital Flight in Zaire" Development and Change, Vol. 29.

Ndikumana, L.,and J.K. Boyce. (2002). "Public Debts and Private Assets: Explaining Capital flight from Sub-Saharan African Countries" World Development.

Ng'eno, N.K. (2000). "Capital Flight in Kenya", in S.I. Ajayi and M.S. Khan (eds).. External Debt and Capital Flight in Sub-Saharan Africa. Washington, DC: The IMF Institute.

Nyatepe-Coo, A. (1994). "Capital Flight in Low-Income Sub-Saharan Africa: The Effects of Political Climate and Macroeconomic Policies", Scandinavian Journal of Development Alternatives.

Nyoni, T (2000). "Capital Flight from Tanzania", in S.I. Ajayi and M.S. Khan (eds).. External Debt and Capital Flight in Sub-Saharan Africa. Washington, DC: The IMF Institute.

Ojo, O.O. (1992). "An Empirical Investigation of Capital Flight in Selected African Countries", African Development Bank, Economic Research Papers, No.17.

Onwioduokit, E.A. (2001). "Capital Flight from Nigeria: An Empirical Re-Examination”, Paper Presented at WIDER Development Conference on Debt Relief, held at Helsinki, Finland 17-18 August.

World Bank (1985). "Case Study: Mexico" in Capital Flight and Third World Debt, edited by D.R. Lessard and J.Williamson (Washington DC: Institute for International Economics).

\section{Notes}

Note 1. Capital flight in all the analysis and discussion in this work refers to adjusted capital flight (ADJKF), which includes misinvoicing. 
Table 1. Data and Computation of Baseline Capital Flight Flows

\begin{tabular}{|c|c|c|c|c|c|}
\hline & $\Delta$ Debt & FDI & CA & $\Delta$ RES & $\mathrm{KF}$ \\
\hline YEAR & Col 1 & Col 2 & Col 3 & $\mathrm{Col} 4$ & Col 5 \\
\hline 1970 & 61.25 & 205 & 368 & 97.45 & -199.20 \\
\hline 1971 & 123.70 & 286 & 406 & 206.09 & -202.39 \\
\hline 1972 & 121.40 & 305 & 342 & -52.78 & 137.18 \\
\hline 1973 & 697.20 & 373 & 8 & 203.29 & 858.91 \\
\hline 1974 & 101.70 & 257 & -4897 & $5,043.72$ & 211.98 \\
\hline 1975 & -193.50 & 418 & -42 & -16.87 & 283.37 \\
\hline 1976 & -349.40 & 339 & 357 & -405.77 & 38.37 \\
\hline 1977 & $1,808.60$ & 440.5 & -1015.98 & -947.61 & 4212.69 \\
\hline 1978 & $1,944.80$ & 210.9 & -3754.3 & $-2,345.58$ & 8255.58 \\
\hline 1979 & $1,153.40$ & 309.6 & 1670.51 & $3,661.25$ & -3868.76 \\
\hline 1980 & $2,676.80$ & -738.9 & 5177.57 & $4,686.90$ & -7926.57 \\
\hline 1981 & $2,499.30$ & 542.3 & -6473.93 & $-6,339.43$ & 15854.96 \\
\hline 1982 & 550.90 & 430.6 & -7281.79 & $-2,282.83$ & 10546.12 \\
\hline 1983 & $5,589.20$ & 364.4 & -4331.8 & -622.64 & 10908.04 \\
\hline 1984 & 209.70 & 189.2 & 122.63 & 472.41 & -196.14 \\
\hline 1985 & 872.80 & 485.6 & 2603.56 & 204.91 & -1450.07 \\
\hline 1986 & $3,568.60$ & 193.2 & 210.88 & -585.87 & 4136.79 \\
\hline 1987 & $6,809.50$ & 610.6 & -73.2 & 83.91 & 7409.39 \\
\hline 1988 & 599.60 & 378.7 & -296.45 & -514.11 & 1788.86 \\
\hline 1989 & 501.00 & 1884.3 & 1089.51 & $1,114.44$ & 181.35 \\
\hline 1990 & $3,316.90$ & 588 & 4988.24 & $2,098.70$ & -3182.04 \\
\hline 1991 & 88.30 & 712 & 1202.56 & 570.81 & -973.07 \\
\hline 1992 & $-4,508.50$ & 897 & 2267.77 & $-3,467.99$ & -2411.28 \\
\hline 1993 & $1,716.90$ & 1345 & -780.39 & 404.96 & 3437.33 \\
\hline 1994 & $2,356.70$ & 1959 & -2127.93 & 13.81 & 6429.82 \\
\hline 1995 & $1,000.20$ & 1079 & -2578.38 & 57.54 & 4600.04 \\
\hline 1996 & $-2,685.90$ & 1593 & 3506.87 & $2,632.30$ & -7232.07 \\
\hline 1997 & $-2,951.70$ & 1539 & 551.55 & $3,506.16$ & -5470.41 \\
\hline 1998 & $1,839.60$ & 1051 & -4243.53 & -481.05 & 7615.18 \\
\hline 1999 & $-1,166.90$ & 1005 & 505.75 & $-1,650.51$ & 982.86 \\
\hline 2000 & $2,227.30$ & 1140 & 7428.97 & $4,460.58$ & -8522.25 \\
\hline 2001 & -313.30 & 1191 & 2477.79 & 545.74 & -2145.83 \\
\hline 2002 & -565.60 & 1874 & 1083.09 & $-3,125.30$ & 3350.61 \\
\hline 2003 & $4,487.10$ & 2006 & 9503.78 & -202.90 & -2807.78 \\
\hline 2004 & 926.60 & 1874.92 & 12264.33 & 329.01 & -9791.82 \\
\hline
\end{tabular}

Source: Author's computations 
Table 2. Trade Mis-invoicing from Nigeria

\begin{tabular}{|c|c|c|c|}
\hline YEARS & EXPORT DISCREPANCIES & IMPORT DISCREPANCIES & TRADE DISCREPANCIES \\
\hline 1970 & -83.055 & 68.85 & -14.205 \\
\hline 1971 & -121.33 & 137.3 & 15.97 \\
\hline 1972 & -122.61 & 88.3 & -34.31 \\
\hline 1973 & -290.78 & 116 & -174.78 \\
\hline 1974 & 418.05 & 56.4 & 474.45 \\
\hline 1975 & 606.09 & 306.37 & 912.46 \\
\hline 1976 & 987.39 & 1168.26 & 2155.65 \\
\hline 1977 & 937.05 & 665.25 & 1602.3 \\
\hline 1978 & 303.7 & 1666.4 & 1970.1 \\
\hline 1979 & -161.98 & -68.34 & -230.32 \\
\hline 1980 & -477.67 & -432.397 & -910.067 \\
\hline 1981 & 2435.44 & 200.82 & 2636.26 \\
\hline 1982 & 2277.048 & -59.496 & 2217.552 \\
\hline 1983 & 1722.809 & 2064.0093 & 3786.8183 \\
\hline 1984 & 849.504 & -8.3074 & 841.1966 \\
\hline 1985 & -708.747 & -726.6585 & -1435.4055 \\
\hline 1986 & 1744.8792 & -2136.8878 & -392.0086 \\
\hline 1987 & -143.3427 & -1011.8118 & -1155.1545 \\
\hline 1988 & 715.6776 & -680.9564 & 34.7212 \\
\hline 1989 & 1785.3336 & -950.1685 & 835.1651 \\
\hline 1990 & 2215.3276 & -1390.0686 & 825.259 \\
\hline 1991 & 4866.754 & -1733.6755 & 3133.0785 \\
\hline 1992 & -519.41 & -327.681 & -847.091 \\
\hline 1993 & 10.365 & 0.33 & 10.695 \\
\hline 1994 & -375.369 & -164.2318 & -539.6008 \\
\hline 1995 & 630.2887 & 237.8159 & 868.1046 \\
\hline 1996 & 278.512 & 77.908 & 356.42 \\
\hline 1997 & 92.006 & 38.2297 & $\mathbf{1 3 0 . 2 3 5 7}$ \\
\hline 1998 & 75.9919 & 43.0762 & 119.0681 \\
\hline 1999 & 229.083 & 126.9009 & 355.9839 \\
\hline 2000 & 313.116 & 94.2676 & 407.3836 \\
\hline 2001 & 285.528 & 123.3588 & 408.8868 \\
\hline 2002 & 1076.4288 & 38.7586 & 1115.1874 \\
\hline 2002 & 721.5316 & -2228.14 & -1506.6084 \\
\hline 2004 & 915.0756 & -5374.8694 & -4459.7938 \\
\hline Cumulative Total & 23488.69 & -9975.08 & 13513.6 \\
\hline Period Average & 671.1053 & -285.002 & 386.1029 \\
\hline Pre SAP Average & 606.8111 & 182.6984 & 789.5095 \\
\hline Post SAP Average & 731.8277 & -726.72 & 5.1078 \\
\hline
\end{tabular}

Total Trade Misinvoicing = Total Export Discrepancies + Total Import Dicrepancies

For exports, positive numbers mean underinvoicing and negative numbers mean over invoicing. For imports, positive numbers mean over invoicing and negative numbers mean under invoicing.

Source: Author's computations 
Table 3. Capital Flight Computations (in US \$ MILLIONS)

\begin{tabular}{|c|c|c|c|c|}
\hline \multirow[t]{2}{*}{ YEAR } & $\begin{array}{l}\text { KF } \\
\text { (base line) }\end{array}$ & $\begin{array}{l}\text { KF } \\
\text { (debt adj cf) }\end{array}$ & ADJ KF & REAL KF \\
\hline & Col. 1 & Col.2 & Col.3 & Col.4 \\
\hline 1970 & -199.20 & -135.13 & -149.33 & -537.546 \\
\hline 1971 & -202.39 & -199.84 & -183.868 & -640.654 \\
\hline 1972 & 137.18 & 704.86 & 670.5481 & 2237.398 \\
\hline 1973 & 858.91 & 263.66 & 88.88382 & 262.1168 \\
\hline 1974 & 211.98 & -71.24 & 403.2069 & 1000.762 \\
\hline 1975 & 283.37 & 139.03 & 1051.486 & 2389.198 \\
\hline 1976 & 38.37 & $2,169.20$ & 4324.855 & 9389.611 \\
\hline 1977 & 4212.69 & $4,316.60$ & 5918.902 & 12109.05 \\
\hline 1978 & 8255.58 & $7,476.44$ & 9446.54 & 17931.93 \\
\hline 1979 & -3868.76 & $-2,359.83$ & -2590.15 & -4368.61 \\
\hline 1980 & -7926.57 & $-7,823.27$ & -8733.33 & -12907.7 \\
\hline 1981 & 15854.96 & $14,779.73$ & 17415.99 & 23586.12 \\
\hline 1982 & 10546.12 & $15,871.62$ & 18089.17 & 24013.24 \\
\hline 1983 & 10908.04 & $5,822.37$ & 9609.186 & 12598.91 \\
\hline 1984 & -196.14 & 304.61 & 1145.802 & 1467.284 \\
\hline 1985 & -1450.07 & -38.95 & -1474.36 & -1897.01 \\
\hline 1986 & 4136.79 & $5,915.07$ & 5523.06 & 7318.219 \\
\hline 1987 & 7409.39 & 166.31 & -988.849 & -1276.59 \\
\hline 1988 & $\mathbf{1 7 8 8 . 8 6}$ & $2,788.74$ & 2823.456 & 3504.352 \\
\hline 1989 & 181.35 & $4,049.08$ & 4884.244 & 5775.386 \\
\hline 1990 & -3182.04 & $-3,405.60$ & -2580.34 & -2946.27 \\
\hline 1991 & -973.07 & $-2,705.54$ & 427.5369 & 487.055 \\
\hline 1992 & -2411.28 & $3,604.14$ & 2757.044 & 3122.361 \\
\hline 1993 & 3437.33 & $3,365.08$ & 3375.779 & 3768.031 \\
\hline 1994 & 6429.82 & $3,992.31$ & 3452.71 & 3804.639 \\
\hline 1995 & 4600.04 & 756.39 & 1624.493 & 1728.184 \\
\hline 1996 & -7232.07 & $-6,794.04$ & -6437.62 & -6691.91 \\
\hline 1997 & -5470.41 & -528.41 & -398.169 & -414.156 \\
\hline 1998 & 7615.18 & $5,611.34$ & 5730.411 & 6112.438 \\
\hline 1999 & 982.86 & $4,272.70$ & 4628.686 & 4896.008 \\
\hline 2000 & -8522.25 & $-10,983.96$ & -10576.6 & -10576.6 \\
\hline 2001 & -2145.83 & $-2,753.81$ & -2344.93 & -2319.18 \\
\hline 2002 & 3350.61 & $8,578.57$ & 9693.757 & 9812.488 \\
\hline 2003 & -2807.78 & $-7,011.99$ & -8518.6 & -8185.45 \\
\hline 2004 & -9791.82 & 5683.21 & -4459.79 & -4036.74 \\
\hline $\begin{array}{l}\text { Cumulative } \\
\text { Total }\end{array}$ & 34859.75 & 55819.45 & 63649.81 & 100516.36 \\
\hline $\begin{array}{l}\text { Period } \\
\text { Average }\end{array}$ & 995.99 & 1594.84 & 1818.56 & 2871.89 \\
\hline $\begin{array}{l}\text { Pre SAP } \\
\text { Average }\end{array}$ & 2447.10 & 2772.64 & 3562.15 & 5526.60 \\
\hline $\begin{array}{l}\text { Post SAP } \\
\text { Average }\end{array}$ & -374.501 & 482.47 & 171.84 & 364.66 \\
\hline
\end{tabular}

Source: Author's computations 


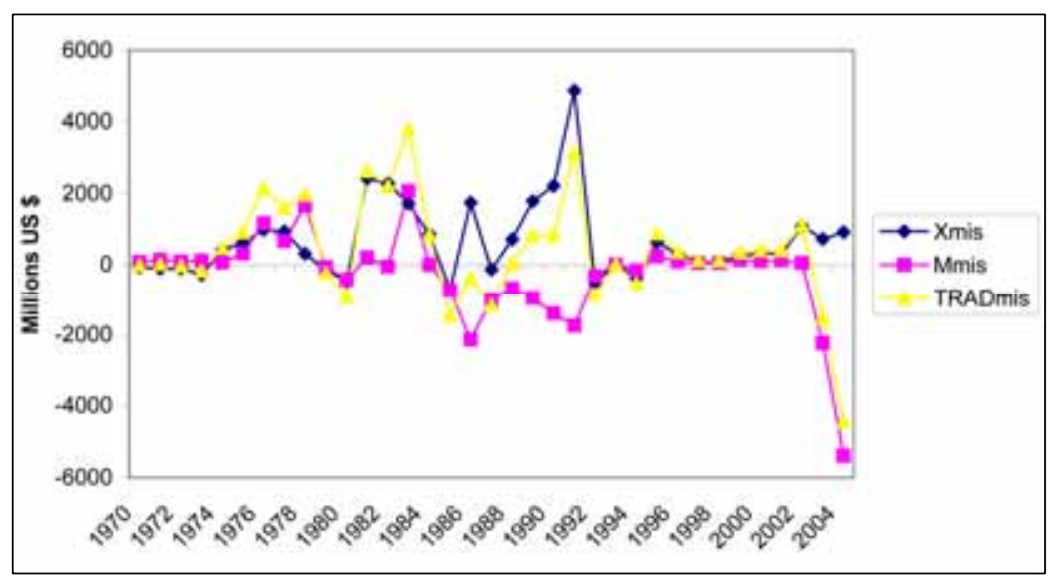

Figure 1. Export Misinvoicing, Import Misinvoicing and Total Trade Misinvoicing in Nigeria

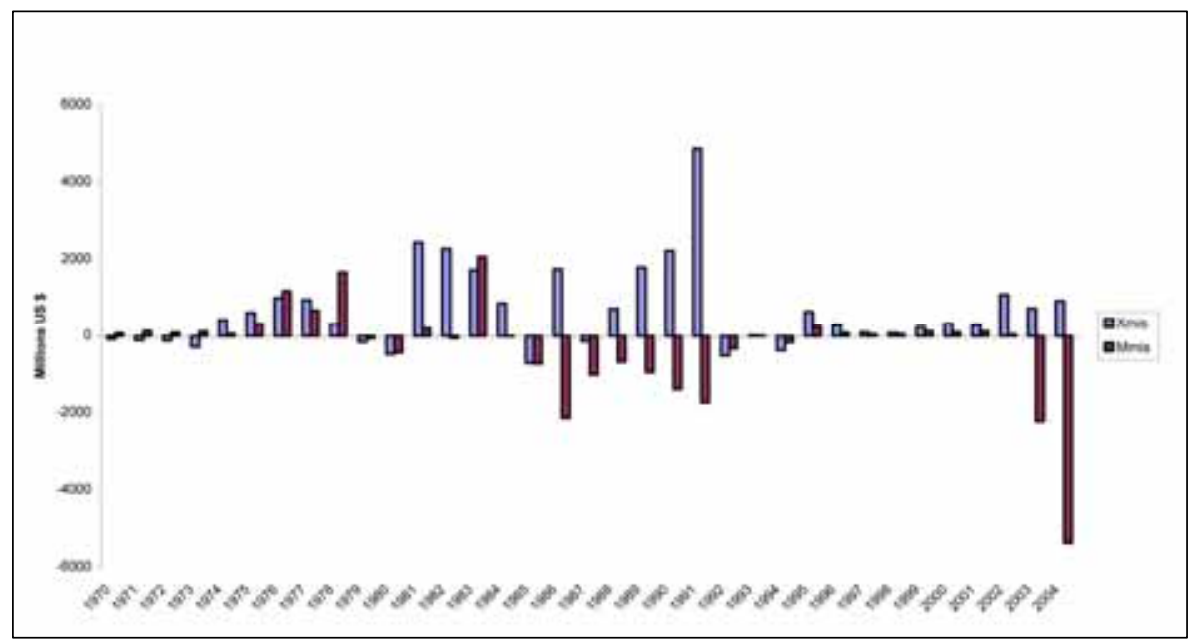

Figure 2. Export and Import Misinvoicing in Nigeria 1970 - 2004

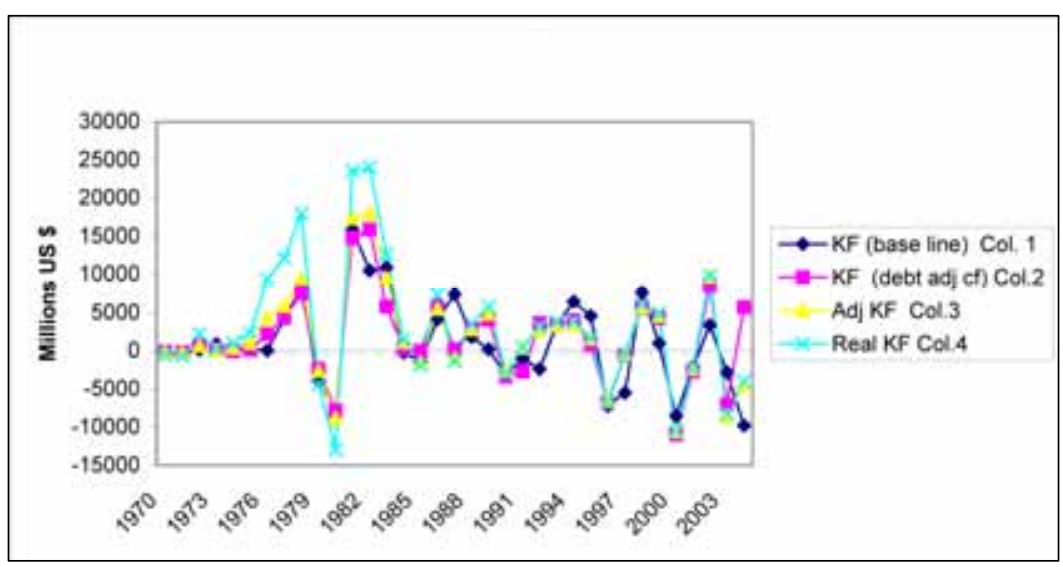

Figure 3. Capital Flight Estimates for Nigeria 1970-2004 


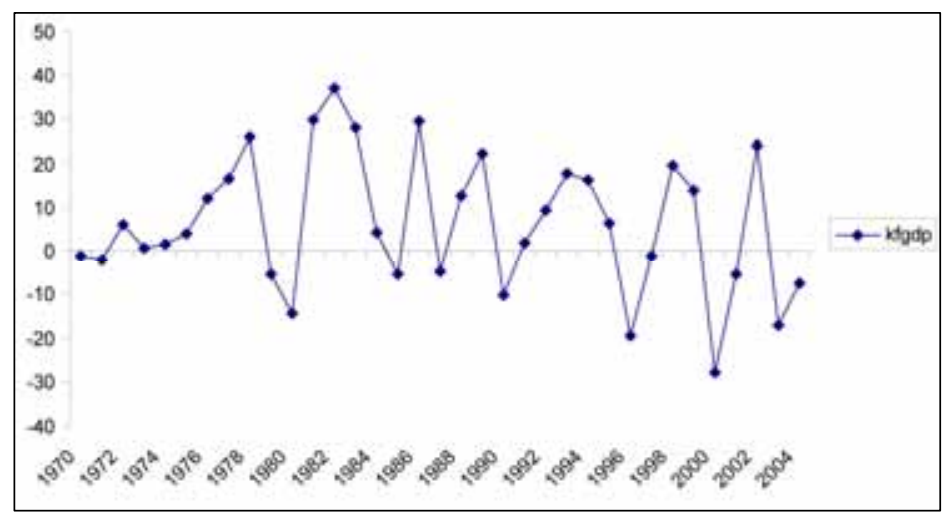

Figure 4. Capital Flight as a Ratio of GDP 1970-20

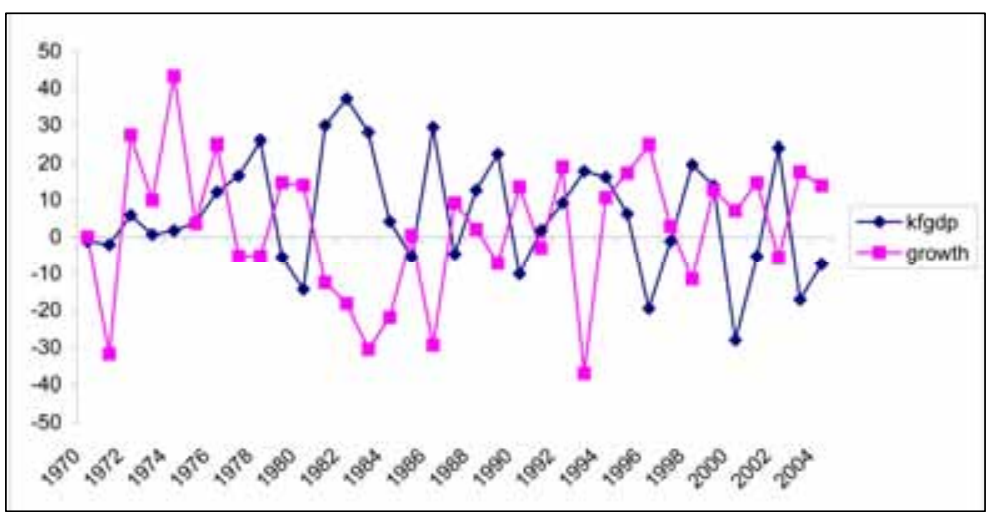

Figure 5. Real Growth (in \%) and Real Capital Flight as a share of GDP

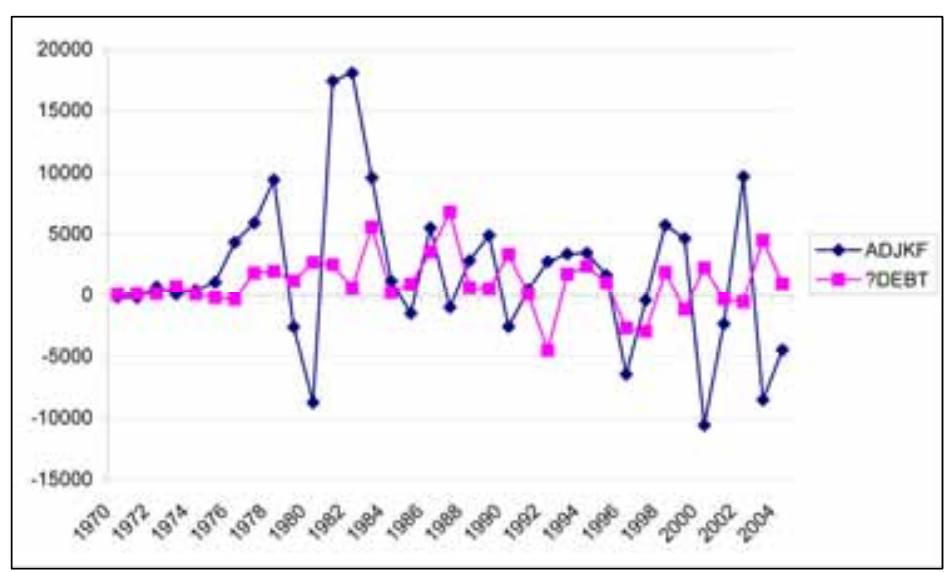

Figure 6. Capital Flight and Change in External Indebtedness: 1970 -2004

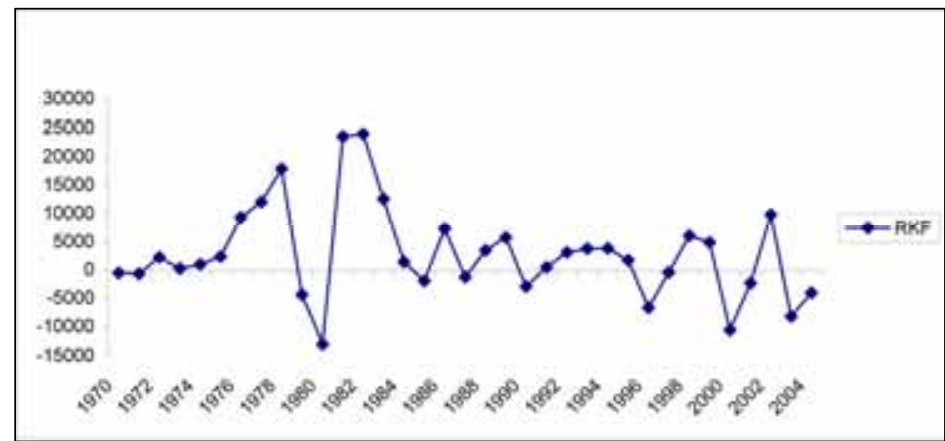

Figure 7. Real Capital Flight (1970-2004) 